\title{
How can we pay for it all? Understanding the global challenge of financing climate change and sustainable development solutions
}

\author{
Jacob Park ${ }^{1,2}$ \\ Accepted: 13 July 2021 / Published online: 21 August 2021 \\ (c) AESS 2021
}

\begin{abstract}
Despite the heightened attention to climate change and sustainable development initiatives by governments, civil society groups, and private companies in the USA and worldwide, the international community is confronted with a question that has existed since the 1992 Earth Summit: how can we pay for it all? To better understand this climate change and sustainable development goals (SDGs) funding dilemma, there needs to be greater clarity around four climate change investment and finance-related questions that are frequently absent or inadequately addressed in the academic and policy literature. Firstly, what are or should be the boundaries of climate change investment and finance when the problem of climate change becomes impossible to separate from biodiversity, land use management, and other dilemmas related to the broader SDGs? Secondly, how we should define and what constitutes "adequate" financial resources to address the climate change and SDGs dilemmas on the global level? Thirdly, why is it important to close the gap between climate change adaptation and mitigation funding levels? Finally, what role should the private sector and business actors play in terms of climate change investment and finance issues? In addition to achieving greater clarity around these four issue areas, I argue in this article that three questions are likely to shape the future success (or failure) of the global climate change investment and finance architecture. One, what is likely path of the United Nations as a global climate change/sustainability governance institution? Two, will the emerging Green New Deal model in the USA and in other countries actually materialize? Three, what is the future outlook for "market-fixing" sustainability-driven enterprises?
\end{abstract}

Keywords Climate change $\cdot$ Climate finance $\cdot$ Impact investment $\cdot$ Sustainable development goals

\section{Introduction}

The late Monty Hempel once observed that the presidential governance of Donald Trump has produced "a growing crisis of legitimacy" regarding the future of democracy and sustainability, a situation he described as the "politics of environmental disruptions" (Hempel 2018 p. 183). More than three years later, the global COVID-19 pandemic, coupled with lackluster global and national leadership in many countries, has led to an unimaginable degree of legitimacy crisis in the way climate change and other global environmental issues are governed. As this post-COVID-19 global environmental governance landscape moves to 2022 and beyond, central to the global legitimacy crisis continues to

\footnotetext{
Jacob Park

jacob.parkVT@gmail.com

1 University of Johannesburg, Johannesburg, South Africa

2 Castleton University, Castleton, VT, USA
}

be the way the international community finances climate change and SDG solutions in the USA and worldwide.

In the case of the USA, climate change is intensifying drought and seasonal variability in temperature, putting a lot of pressure on state governments to invest in policy measures to address water scarcity and electric grid resiliency. Four months after more than 100 people died in Texas during a February 2021 storm that crippled the power grid as demand for heat increased at the same time as electrical plants went offline, a record-breaking heatwave struck in June 2021 impacting Texas and the Western United States, which is already facing the worst drought in two decades and causing enormous pressure on the electrical grids stressed by a spike in air-conditioning and consumer energy demand (Kasakove 2021).

In the global context, to understand how and why policy lever the international community uses to finance climate change and SDG solutions represent such a critical legitimacy crisis, we need to start with the recognition that traditional national government-led development assistance 
programs have always been non-binding "voluntary" pledges from the wealthy OECD bloc of countries in North America, Europe, and East Asia to finance climate change and SDG activities as well as fund the operations of the United Nations (UN), World Bank, and other related international organizations (e.g., International Committee of the Red Cross, UN Environment, UN Development Program). At the 1992 U.N. Conference on Environment and Development (UNCED), or more popularly known as the Earth Summit, the late Maurice Strong, the UNCED Secretary General, defined one of the "success" markers at the international environmental conference "as a minimum of an extra $\$ 10$ billion a year of 'new money' from Western countries to finance summit commitments in the Third World" (Pearce 1992 p. 4).

While mechanisms for additional funding were announced at UNCED, including the launch of a new financing mechanism (Global Environment Facility ${ }^{1}$ ), only about $\$ 2$ billion in "additional" funding were allocated, far short of the \$125 billion extra funding (beyond existing development assistance funding levels) that was needed (Davidson 1992). Although there has always been a gap between what the international community needs and what the international community has in terms of available resources, the gap in climate change investment and finance appears to be widening dramatically. Meeting the goals of the Paris Climate Agreement is likely to cost over $\$ 12$ trillion over the next 25 years, with an annual gap of $\$ 2.5$ trillion in financing sustainable development goals (SDGs) between 2015 and 2030 (UN 2014).

To address the growing concern of an ever-increasing climate change and SDG financial obligations, the G-7 countries, for instance, have taken a number of measures, including the group's environment ministers' agreement to phase out new direct government support for "carbon-intensive international fossil fuel energy" in May 2021 and the group's finance ministers' agreement to require companies to disclose their climate-related risks in their financial statements in June 2021 (McDonnell 2021). While these measures will no doubt help climate change and SDG financing indirectly (e.g., by reducing climate-related risks in investment and project financing), Mitchell et al. (2021) estimate that if one were to analyze the progress made since the pledge at the 2009 United Nations Framework Convention on Climate Change (UNFCCC) Conference in Copenhagen (and affirmed in the 2015 Paris Climate Agreement) by developed countries to mobilize $\$ 100$ billion in climate finance, only $\$ 43$ billion or less than half in "new and additional" total development finance (including flows from official aid, multilateral contributions, and less-concessional finance, including export credits) has materialized.

\footnotetext{
1 According to Global Environment Facility (https://www.thegef.org/ about-us), Global Environment Facility "has provided over $\$ 17.9$ billion in grants and mobilized an additional $\$ 93.2$ billion in co-financing for more than 4500 projects in 170 countries" since 1992.
}

Moreover, if one were to assess which developed countries have contributed their "fair share" of the total climate finance contribution since the 2009 UNFCCC Conference, Colenbrander et al. (2021) argue that France and Germany are paying their fair share of climate finance, while the USA contributed just 7\% of its fair share in 2017-2018. If one used a more stringent definition of climate finance, Colenbrander et al. (2021) estimate that Germany, Japan, and the UK are paying 40-45\% of their fair share, while Australia, Canada, and the USA contributed less than 5\% of their fair share in 2017-2018.

Despite greater attention to climate change and sustainable development initiatives by national governments, civil society groups, and private companies, the international community is confronted with a critical question which has existed since the 1992 Earth Summit: how can we pay for it all? To better understand this funding dilemma, there needs to be greater clarity around four climate change investment and financerelated issue areas that are frequently absent or inadequately addressed in the academic and policy literature. Firstly, what are the boundaries of climate change finance and investment when the problem of climate change as environmental science dilemma is almost impossible to separate from biodiversity, land use management, and other global environmental issues? Secondly, what constitutes "enough" or "adequate" financial resources to address the climate change dilemma on the global level? Thirdly, how do we close the gap between climate change adaptation and mitigation funding? Finally, what role should the private sector and business actors play in terms of climate change investment and finance?

In addition to achieving greater clarity around these four issue areas, I argue in this article that three questions are likely to shape the future success (or failure) of the global climate change investment and finance architecture. One, what is likely path of the United Nations as a global climate change/sustainability governance institution? Two, will the emerging Green New Deal model in the USA and in other countries actually materialize? Three, what is the future outlook for "market-fixing" sustainability-driven enterprises?

\section{Conceptualizing the boundaries of climate change as a global sustainability dilemma in the era of the Anthropocene ${ }^{2}$}

Three years ago, Europe turned into a "modern-day version of the biblical plagues" with cows dying from a drought in Switzerland, fires engulfing forests in Sweden, and record temperatures being recorded in Spain and Portugal in the

\footnotetext{
2 According to Steffen et al. (2015), Paul Crutzen proposed in 2000 that Earth had left the Holocene period and has entered a new geological epoch, the Anthropocene, driven by the impact of human activities on the Earth System.
} 
Table 1 Six transformations needed to achieve the UN sustainable development goals

- Sustainable development is a societal rather than an environmental challenge

- Responsible consumption and production cut across several of the other transitions so adopting some sort of a circular economy approach and reducing demand is important

- It is possible to decarbonize the energy system around 2050 while providing clean and affordable energy for all, including through energy efficiency, more renewables, and electrification

- Achieving access to nutritional food and clean water for all, while protecting the biosphere and the oceans, requires more efficient and sustainable food systems

- Transforming our settlement patterns will benefit the majority of the world population—such as through "smart" infrastructure, decent housing, and high connectivity

- Science, technology, and innovations is a powerful driver, but the direction of change needs to support sustainable development. In particular, much depends on the way the world will put the information technology revolution to use

Source: Adapted from Stockholm Resilience Centre (2018)

summer of 2018 (Rubin 2018 p. 6). Given the growing global public concerns surrounding extreme weather events in recent years, should climate change be regarded as the most important or just one of many important environmental problems in this era of the Anthropocene? Are the environmental and natural disasters the international community has experienced in the past couple of years yet another signal of intensifying climate change or possibly something else?

Because climate change has become the most important global challenge confronting the international community, there is a risk that all other environmental issues, whether or not they are directly related to the causes and effects of climate change, like land use management, urbanization, among others, will be viewed myopically as well as exclusively through the lens of global climate change. Since issues like desertification can get greater attention as a funding priority if it were framed as a climate change adaptation and/or mitigation problem, the tendency to frame issues as a climate change priority is perhaps not surprising.

The policy challenge that results from this framing problem is that carbon emission reduction measures are not always neutral in terms of their social (e.g., building an energy-efficient/low carbon producing industrial facility in a land-scarce community setting) and ecological impacts (e.g., favoring fast-growing plants and trees that are better at carbon absorption over old-growth forest stock). For instance, if one were to examine the World Economic Forum's Global Risk Reports since the publication of its first report in 2006, all five categories of global environmental risks ("extreme weather events and temperatures; accelerating biodiversity loss; pollution of air, soil and water; failures of climate change mitigation and adaptation; and risks linked to the transition to low carbon") have risen in terms of their risk profile (Martin 2018).

Not only these risks ranked highly on the likelihood and impact scales, all five environmental risks have direct (e.g., failures of climate change mitigation and adaptation) and/ or indirect (e.g., extreme weather events and temperatures) linkages to climate change (Martin 2018). Similarly, if one were to look at the six transformations that are needed to achieve the SDGs as highlighted (see Table 1) in the Stockholm Resilience Centre report (2018), one can see to what degree the conceptualization of climate change and environment/sustainable development domains has been blurred. In terms of conceptualizing global solutions, it is very difficult to see what meaningful differences exist between the climate change and the broader SDG domain.

\section{Defining what is "enough" in the climate change investment and finance architecture}

In his influential 1992 book, Alan Durning asks, "how much is enough? What level of consumption can the earth support? Many of these questions cannot be answered definitively, but ... unless we see that more is not always better, our efforts to forestall ecological decline will be overwhelmed by our appetites" (Durning 1992). This issue and question of "how much is enough" represents a good conceptual frame to highlight the past, current, and future gap in terms of climate change investment and finance. More than any other issue, the failure to deliver on the promise of a secure and stable funding can only be described as the "original sin" of global climate change/sustainability governance. This is why climate change investment and finance-related issues serve as such important criteria to assess whether or not the USA and other wealthier OECD countries have lived up to their historical responsibilities under the UNFCCC Principle of Common, But Differentiated Responsibilities (Zhang and Pan 2016).

As part of the climate change finance agreement reached at the 2009 UNFCCC conference in Copenhagen, the international community agreed to establish a climate change finance architecture as well as to provide $\$ 30$ billion in "fast-start" finance and to mobilize $\$ 100$ billion long-term finance starting in 2020. A new global climate change financial entity, the 
Green Climate Fund, was also launched in 2010. While most observers would describe the 2015 Paris Climate Change Conference as a "success," there was no progress in reaching a global consensus in terms of how to share the financial responsibility of providing $\$ 100$ billion annually between the industrialized and developing countries (Zhang and Pang 2016).

If one were to define the climate change investment and finance flows narrowly as financial resources coming from "multilateral climate funds" 3 (including the Green Climate Fund, Adaptation Fund, etc.), 152 climate change investment and finance projects valued at over $\$ 2$ billion were implemented across 70 countries in 2017, with half of the total (\$1 billion) coming from the Green Climate Fund (Watson et al. 2018). Seven multilateral climate funds were responsible for $\$ 11.7$ billion for 967 projects between 2001 and 2016 and helped mobilize more than $\$ 70$ billion in additional financing from the private sector and other sources (Amerasinghe et al. 2017). If one were to use a broader measure of climate change investment and finance flows to include a wide range of public, private, and public-private initiatives (e.g., electric utility investing in a green grid project), climate change investment and finance flows would reach $\$ 612$ billion in 2017 (Buchner et al. 2019).

While the global research on climate change investment and finance flows is getting better, particularly in terms of the OECD industrialized countries, the academic scholarship and policy research on climate change investment and flows in the developing world ${ }^{4}$ still remain "highly uncertain and ... (characterized by) unavailability of data, methodological variations, and disagreements over what should be counted as climate finance" (Selin 2016 p. 1). The question of "how much is enough" gets even more interesting if one were to explore future climate change investment and finance needs and priorities. The UNEP Finance Initiative estimates that the costs of the transition to low carbon and climate-resilient economies will need an investment of $\$ 60$ trillion between 2017 and 2050 (Shine 2017), while the Global Commission on the Economy and Climate (2014 and 2016) concludes that $\$ 89$ trillion or about $\$ 6$ trillion annually is likely to be needed between 2015 and 2030 to achieve the more ambitious goal of low carbon emissions and climate resiliency in cities, energy systems, and in other sectors.

\footnotetext{
3 A comprehensive list of which institutions make up the "multilateral climate funds" can be found here: https://climatefundsupdate.org/ the-funds.

4 There are a number of important exceptions to this assessment, most notably the climate-resilient development research of the London-based International Institute for Environment and Development (IIED https://www.iied.org/climate-resilient-development), the sustainability \& finance work of the Washington D.C. World Resources Institute (https://www.wri.org/our-work/topics/finance), and the climate finance \& investment analysis of the London-based Climate Policy Institute https://www.climatepolicyinitiative.org.
}

\section{Differentiating the climate change finance of adaptation versus mitigation}

Climate change actions can be categorized into two major types: adaptation or mitigation. Adaptation describes "actions that countries will need to take to respond to the impacts of climate change that are already happening ... (as well as future actions) ... that can reduce our vulnerability to climate change impacts (e.g. investing in flood prevention practices)" (UNFCCC 2018a). Mitigation refers to actions that directly decrease "the amount of emissions released into the atmosphere" and indirectly reduce "the current concentration of greenhouse gas emissions by enhancing sinks (e.g., increasing the area of forests)" (UNFCCC 2018b). While both of these climate change action types are important, it is important to disaggregate climate mitigation investment flows from climate adaptation because the climate mitigation finance is so heavily tilted toward cities and urban regions in developed countries away from rural communities and regions in the developing world, where adaptation finance is the key to address community-based solution, particularly in the context of sub-Saharan African countries. Sub-Saharan Africa as a region does not, ironically, emit enough greenhouse gas emissions to benefit from most climate mitigation projects.

Consequently, only $7 \%$ of the total climate investment and finance flows went to adaptation activities in 2016, while $93 \%$ of the total climate finance flows went to fund climate mitigation activities (Oliver et al. 2018). Although adaptation finance rose significantly to $\$ 30$ billion in the 2017-2018 time period, a 35\% increase from 2015-2016 levels, adaptation finance is still significantly short of what is needed worldwide (Buchner et al. 2019). Because climate change investment and finance flows tend to stay within the same country and region (that is, German companies tend to invest in solar energy projects based in Germany or within the European Union), the investment flow tilts toward climate mitigation activities has particularly negative consequences for economically insecure, investment capital scarce countries in the developing world.

Economically insecure rural communities in the developing world are often the most vulnerable to the impacts of climate change, but these same communities are also tragically the most in need of financial support to strengthen the local resilience to climate change (Soares et al. 2017). While one can understand the economic rationale of funding a solar power project in Denmark over a climate-friendly agricultural project in Niger from a private energy market risk and return perspective, the gap between what is required versus what is available in terms of adaptation finance is projected to worsen. According to the UN Environment Adaptation Finance Gap report (2016), the cost of adapting to climate 
change may range between $\$ 140$ and $\$ 300$ billion per year in 2030 and between $\$ 280$ and $\$ 500$ billion per year in 2050 , due in part to worsening effects of climate change in the developing world.

\section{Rethinking private authority as a global climate change and sustainability actor}

According to Hoffman (2018), the first phase of business sustainability, or what he refers to as "sustainable business 1.0," is based on a model of business responding to sustainability-related market shifts. More than $90 \%$ of private business chief executive officers, for instance, state that sustainability is important to their company's success and working toward developing strategies to "fit" the sustainability trends. By contrast, the next phase of business sustainability, or what Hoffman refers to as "sustainable business 2.0" needs to be based on a model in which the private sector is leading the market transformation process toward greater sustainability. Even if one agrees with the premise that "changing the way we do business is essential to addressing the challenges of environmental degradation" (Hoffman 2018, p. 35), it is not clear if the private sector has the capacity or even the desire leading the market transformation process toward greater sustainability.

Jessica Green's concept of the "private authority" (Green 2013, p. 4-5) provides a useful theoretical frame to contextualize the role of the private sector as a climate change investment and finance actor. According to Green (2013), there are two types of private authority operating in the climate change governance arena. In the first type, states delegate authority to private actors, which Green refers to as "delegated private authority," in which the state in the form of say the UNFCCC "delegates" the governance of Kyoto Protocol's Clean Development Mechanism to private actors. In the second type, business actors generate their own rules and persuade actors and institution to adopt them. In what Green refers to as "entrepreneurial state authority" (Green 2013 p. 4-5), private actors create climate change and other sustainability governance rules without an explicit delegation of authority from states. Forest Stewardship Council's sustainable forestry standards and the U.S. Green Building Council's Leadership in Energy and Environmental Design rating system are both examples of such "entrepreneurial state authority."

Conceptualizing private authority in the climate change governance arena as one of private and state authority, as opposed to private versus state authority, is important since any meaningful climate change solutions, without some form of private sector collaboration, are probably impossible. In a rapidly changing transnational climate change governance system, there is a wide range of business, civil society, and hybrid (business/civil society) advocacy networks (Macleod and Park 2011) that collaborate on some issues and competing on other issues while operating in the same climate change market institutional space. The cost of implementing the Paris Climate Agreement is likely to cost over $\$ 12$ trillion between 2015 and 2030 and an annual gap of \$2.5 trillion in financing SDGs over the same time period (United Nations 2014) and it is unclear how these climate change and SDGs funding goals can be achieved without effective cross-sector collaboration.

Virtually, all of the innovative climate change/SDGs financing mechanisms currently under consideration involve higher and more integrated models of cross-sector collaboration, most notably with the global financial sector. Some noteworthy examples of climate change-focused cross-sector collaborations include climate bonds (fixed-income based financial approach to address climate change); forest resilience bond (a pay-for-performance mechanism for private investors to invest in forest restoration that prevents wildfires and to address water scarcity issues); clean energy investment trust (an investment structure that aligns and supports institutional investments into renewable energy); and land degradation fund (in which private investments are channeled to profit-generating sustainable land management and land restoration projects) (Bartlett et al. 2017).

Whereas books such as Lenox and Chatterji (2018) and O'Leary and Valdmanis (2020) believe in the criticality of the business sector as part of this cross-sector collaboration and innovation, it should be noted that there is not an academic scholarship consensus on what role private sector should play in global climate change and sustainability governance. Using a political ecology framework, Checker (2020) analyzes the hidden costs as well as the contradictions of New York City's ambitious green real estate and sustainable business development agenda, while DuPuis and Greenberg (2019) question whether the framing of such issues as "climate resiliency" and public-private partnership might unintentionally lead to a pro-business development agenda at the expense of low-income, vulnerable community members.

\section{From despair to hope: Designing a new approach to global climate finance and investment architecture}

At a 2018 UNFCCC-sponsored climate change conference held in Bangkok, Thailand, one issue and question stood central to the policy discussion at the conference: how should Article 9.5 of the UN climate change convention (which states that developed country parties [e.g. 
USA] should biennially communicate their financial contributions to developing country parties) be defined? Should it be viewed as a clearly defined goal that promises a specific amount of financial disbursement from the OECD industrialized countries to the developing world or should Article 9.5 be more accurately described more of an aspirational goal of mobilizing and building the process of partnerships to support capacity building? (ENB 2018).

Over the short term, disagreements over how to define Article 9.5 are likely to continue in 2021 and subsequent couple of years afterwards. The failure to meet the promise of mobilizing an annual disbursement of $\$ 100$ billion by the industrialized countries at the 2009 UNFCCC conference, coupled with funding only one-third of the $\$ 10$ billion Green Climate Fund (GCF) and former U.S. President Donald Trump's decision to cancel the promise of $\$ 2$ billion U.S. contribution to the GCF in June $2017,{ }^{5}$ deepened a sense of pessimism among many developing countries and civil society advocacy groups as recently as 2017 . As Meena Raman, legal advisor to the Third World Network, observed during the Trump Administration: "the fund of hope is becoming a fund of hopelessness" (Ives 2018, p. A10). Fueling the feeling of despair is the cumulative impact of intensifying drought and other climate changerelated extreme weather patterns in northern Kenya, Somalia, and other countries/regions in the Horn of Africa. This region has experienced four severe droughts in the last two decades, which has pushed some of the world's poorest people and vulnerable communities to severe food insecurity conditions (Sengupta 2018).

Over the long term, three questions are likely to shape the future success (or failure) of the global climate change investment and finance architecture. First (and continuing a bit more on the theme of despair), will the United Nations as a global climate change/sustainability governance body, continue to follow the post-1992 UNCED model of process (e.g., organizing meetings, deliberating on resolutions) taking precedence over results (e.g., achieving specific goals and measures) $?^{6}$ Second, what impact will the emerging Green New Deal in the USA and in other countries accelerate new climate change finance and investments? Third, what is the future outlook for new models of "market-fixing" sustainability-driven enterprises?

\footnotetext{
5 President Joseph Biden pivoted from former President Trump's 2017 decision and announced in April 2021 that the USA will be pledging $\$ 5.7$ billion in climate change development assistance to developing countries.

6 The post-UNCED/Rio Summit analysis in this paper draws on chapter 1 of Park, J., Conca, K., Finger, M. 2008. eds. The Crisis of Global Environmental Governance: Towards a New Political Economy of Sustainability. New York: Routledge.
}

\section{Will it be business as usual in terms of climate change investment and finance-related issues or will there be a breakthrough in this emerging post-pandemic global governance system?}

When representatives of governments, civil society, and private companies converged in Brazil for the 1992 UNCED conference, the mood of the international community was cautiously optimistic. Perhaps more than any other international negotiation process leading up to the early 1990s, the UNCED process allowed the international community to imagine a world in which governments can come together to work toward a collaborative path toward long-term sustainability. What was a contentious debate then and one continues to persist to this day centered on the core question of how to finance this global vision of sustainable development (Park et al. 2008). Should the industrialized countries pay for the costs of additional measures undertaken by developing countries to tackle global environmental problems? This notion of "additionality," that is financial commitments beyond existing development assistance, "became a rallying cry for the developing countries in the negotiations on Agenda 21 prior to the Earth Summit, and something that has been raised many times since: a desire for a sustainable future is rarely followed up with adequate institutional support and economic resources" (Park et al. 2008, p. 4).

Perhaps the most compelling critique of the UNCED process took place ten years after the Earth Summit when the world's leaders gathered for the World Summit on Sustainable Development in August 2002. "Only ten years after the Rio Summit, the cracks in the official vision had grown into open fissures" (Park et al. 2008, p. 4). When the international community gathered in Brazil in 2012 for the UN Conference on Sustainable Development or Rio +20 , the diplomatic progress was still hampered by the core questions of "who must do what and who pays?" (Tollefson and Gilbert 2012).

\section{Will the Green New Deal legislation in the USA and in other countries lead to new flows of climate change finance and investments?}

In the version of the Green New Deal ${ }^{7}$ (GND) proposed initially by Senator Edward Markey and Representative Alexandria Ocasio-Cortez in February 2019, there is an ambitious language of transitioning the USA to $100 \%$ renewable, zero emission energy sources, dramatic new investments into zero emissions electric cars, and transportation systems. What is missing, at least for now, is an equally ambitious vision of

\footnotetext{
7 House Resolution 109 https://www.congress.gov/bill/116th-congr ess/house-resolution/109/text
} 
how the transition to $100 \%$ renewable, zero emission energy sources will be financed. To bridge the annual gap of $\$ 2.5$ trillion in financing sustainable development goals between 2015 and 2030 (UN 2014) in the USA and worldwide, there is a critical need to go beyond the governmental sector in terms of a long-term climate change investment and finance solution. The transition to a low carbon economic future in the USA and worldwide will require a sustained long-term strategy of collaboration with the private sector, particularly with institutional financial investors, in order to tap into the \$200 trillion in private capital markets in the USA and worldwide (Della Croce and Hindle 2019).

To enable this sustained long-term strategy of private financial market collaboration, there needs to be the design and development of new blended financial instruments, ${ }^{8}$ which are investment approaches that mix private and public sources to achieve a specific social and environmental impact (Bartlett et al. 2017). Case in point: approved as a $\$ 400$ million general obligation bond in November 2017, the Miami Forever Bond, ${ }^{9}$ for instance, used the municipal bond market to raise $\$ 400$ million to fund a wide range of urban climate change resilience projects in Miami and nearby communities in Florida.

\section{What is the future outlook for new models of "market-fixing" sustainability-driven enterprises?}

One key issue that is likely to shape the future success (or failure) of the global climate change investment and finance architecture is the future outlook for new climate-resilient business enterprises, whose models are built on an integrated goal of accelerating low carbon pathways, adaptation finance, and climate justice toward long-term "market transformation" 10 impact in the developing world. What makes these enterprises "transformative" rather than just "incremental" is that their business model focus extends beyond "market fixing" to what Mazzucato (2016) calls "market creating." Similar in business philosophy to such concepts as "regenerative" (Rodale Institute 2014) in the case of agriculture and food system and "sustainability business model" (Stubbs and Cocklin 2008) and "inclusive market development" (Mair et al. 2012) in the business management field, these "market creating" climate-resilient enterprises reflect two trends which are currently taking place worldwide.

\footnotetext{
${ }^{8}$ A list of blended financial instruments, which the Rockefeller Foundation includes as part of its Zero Gap Funds initiative, can be found here: https://www.rockefellerfoundation.org/initiative/zero-gapfund.

${ }^{9}$ Details of the Miami Forever Bond can be found here: https://www. miamigov.com/Notices/News-Media/Miami-Forever-Bond-Projectto-Mitigate-Effects-of-Sea-Level-Rise.

${ }^{10}$ From the idea of market integration versus market transformation as highlighted by Hoffman (2018)
}

The first trend stems from a growing consensus that a much stronger global progress is needed on a wide range of climate mitigation/low carbon pathway technologies and business models related to energy efficiency, energy storage technologies, zero emission vehicles, and carbon capture and storage to keep our planet below $2{ }^{\circ} \mathrm{C}$ (Brown and Granoff 2018). While there is wide agreement that large amounts of climate change investment and finance need to be mobilized (e.g., $\$ 1$ trillion in additional clean energy investment is required to limit global temperature rise below $2{ }^{\circ} \mathrm{C}$, according to Ceres (2014)), there is a critical need to move beyond the goal of establishing ever more stringent yet elusive global targets to better understanding what types of climate change finance and investments are likely to result in some blend of mitigation and adaptation impact and effectiveness (Brown and Granoff 2018), particularly in the context of India, Vietnam, and other climate fragile developing countries. With climate change-related financial and economic losses set to reach $\$ 1.5$ trillion between 2003 and 2013 (Hallmeyer and Tonkonogy 2018), the private financial market (e.g., in the insurance sector) for investors and companies to measure and manage their risks from climate change is likely to remain strong in the coming decades.

The second trend stems from the growing recognition that climate justice needs to play a greater role in any meaningful climate change-driven market transformation process. Climate change justice scholarship has traditionally been shaped by the perspectives of philosophical and environmental ethics (Jamieson 2010) examining climate change in the context of historic and current carbon emissions or from the perspectives of sociology (Roberts and Parks 2007) discussing how social movements have united and gained traction under the climate change policy umbrella. While the role of business in global climate change governance is growing in the academic literature (see Green 2013 and Paterson 2018), and extensively in the policy literature (e.g., World Economic Forum, Business for Social Responsibility, among others), what has been traditionally been missing in both the academic and the policy research literature is the explicit focus on climate change justice and the role it can and needs to play at the nexus of climate change governance and investment/ finance (Gifford and Knudson 2020).

\section{Conclusion}

Due to the intense focus on responding to the global COVID-19 health crisis, it is easy to overlook that India recorded one of its intense heat waves, with a temperature spike in the city of New Delhi that reached 118 degrees (Fahrenheit) or 48 degrees Celsius, in May 2020 (BBC 
2020). In the case of Vietnam, this Southeast Asian country suffered one of the worst cases of flooding in its modern history in October 2020 (Hollingsworth 2020), while the Western United States states are experiencing record temperatures, intensive wildfires, and the worst drought in two decades in summer of 2021. Monty Hempel (2014) once observed that "knowing that change is needed is clearly not enough to motivate it in most human behavior." Rather, "individuals must have a sense of urgency and personal control over prospective outcomes and goal achievement before they will commit to meaningful action or new behaviors."

Whether the election of President Joseph Biden and the appointment of John Kerry as the new climate change special envoy in November 2020 creates that "sense of urgency" to mobilize greater climate change investment and finance support for the developing world remains to be seen. Re-entering the Paris Climate Change Agreement process and other multilateral forums is one thing; making long-term commitments to climate change investment and finance in an extremely divided Washington D.C. political environment represents a much steeper as well as a completely different level of policy challenge. What Hempel (2018) refers to as the "politics of environmental disruption" is likely to continue in 2021 and beyond, which raises both short-term and long-term questions regarding the trajectory of global climate change and sustainability as a governing principle in the Biden and Harris administration.

\section{References}

Amerasinghe N, Thwaites J, Larsen G, Ballesteros A (2017) The future of the funds: exploring the architecture of multilateral climate finance. World Resources Institute: Washington DC

Bartlett V et al (2017) What matters: investing in results to build strong, vibrant communities. Federal Reserve Bank of San Francisco and Nonprofit Finance Fund: San Francisco, CA/ New York City

BBC (2020) India heatwave: Delhi temperature hits 47C as north India reels. Retrieved October 15, 2020 from https://www.bbc. com/news/world-asia-india-52816493.

Brown J, Granoff I (2018) Deep decarbonization by 2050: rethinking the role of climate finance. Climate Policy Institute: London, UK.

Buchner, B. et al. (2019) Global landscape of climate finance 2019. Climate Policy Institute: London, UK

Ceres (2014) Investing in the clean trillion: closing the clean energy investment gap. Ceres, Boston, MA

Checker M (2020) The sustainability myth environmental gentrification and the politics of justice. NYU Press, New York City

Colenbrander S, Cao Y, Pettinotti L (2021) A fair share of climate finance?: An initial effort to apportion responsibilityfor the $\$ 100$ billion climate finance goal. ODI: London, UK

Davidson J (1992) The Earth Summit. Dev Pract 2(3):201-203

Della Croce R, Hindle J (2019) Flying blind in climate change investing. Centre for Centre for Climate Finance \& Investment. April 8. Imperial College Business School: London, UK
DuPuis M, Greenberg M (2019) The right to the resilient city: progressive politics and the green growth machine in New York City. J Environ Stud Sci 9(3):352-363

Durning A (1992) How Much Is Enough? W.W. Norton \& Company: New York City

Earth Negotiations Bulletin (ENB). (2018) Bangkok Climate Change Conference Summary \& Analysis - September 2018. http://enb. iisd.org/climate/sb48-2.

Gifford L, Knudson C (2020) Climate finance justice: international perspectives on climate policy, social justice, and capital. Clim Change 161:243-249. https://doi.org/10.1007/ s10584-020-02790-7

Global Commission on the Economy and Climate (2014) Better growth, better climate: the new climate economy report. Global Commission on the Economy and Climate, Washington, DC

Global Commission on the Economy and Climate (2016) The sustainable infrastructure imperative. Global Commission on the Economy and Climate, Washington DC

Green J (2013) Rethinking private authority agents and entrepreneurs in global environmental governance. Princeton University Press, Princeton, NJ

Hallmeyer K, Tonkonogy B (2018) Designing technical assistance activities for adaptation and resilience companies. Climate Policy Institute: London, UK

Hempel M (2014) Ecoliteracy: knowledge is not enough. In: State of the World 2014. State of the World. Island Press: Washington, DC

Hempel M (2018) AnthropoTrumpism: Trump and the politics of environmental disruption. J Environ Stud Sci 8:183-188

Hoffman A (2018) The next phase of business sustainability. Stanford Social Innovation Review. Spring, 34-39.

Hollingsworth J (2020) More than 100 dead as Vietnam reels from 'worst floods in decades. Cable News Network. October 21. Retrieved November 20, 2020 from https://www.cnn.com/2020/ 10/21/asia/vietnam-floods-weather-intl-hnk/index.html.

Ives M (2018) Promised billions for climate change, poor countries are still waiting. New York Times. September 10, A10.

Jamieson D (2010) Climate change, responsibility, and justice. Sci Eng Ethics 16:431-445

Kasakove S (2021) Warning of Extreme Heat Across U.S. Southwest. New York Times. A23

Lenox M, Chatterje A (2018) Can business save the earth? Innovating our way to sustainability. Stanford University Press, Palo Alto, CA

Macleod M, Park J (2011) Financial activism and global climate change: the rise of investor-driven governance networks. Global Environ Polit 11(2):54-74

Mair J, Marti I, Ventresca M (2012) Building inclusive markets in Bangladesh: How intermediaries work institutional voids. Acad Manag J 55(4):819-850

Martin A (2018) Climate and tech pose the biggest risks to our world in 2018. World Economic Forum. https://www.weforum.org/ agenda/2018/01/the-biggest-risks-in-2018-will-be-environmen tal-and-technological.

Mazzucato M (2016) From market fixing to market-creating: a new framework for innovation policy. Ind Innov 23(2):140-156

McDonnell T (2021) It's time for G7 countries to put up or shut up on climate. Quartz. June. https://qz.com/2019457/g7-countries-areshortchanging-the-climate-by-billions-of-dollars.

Mitchell I, Ritchie E, Tahmasebi A (2021) Is climate finance towards $\$ 100$ billion "new and additional". Center for Global Development: Washington DC

O'Leary M, Valdmanis W (2020) Accountable: the rise of citizen capitalism. HarperCollins, New York City

Oliver P, Tonkonogy B, Wang D, Wang X (2018) Supporting the momentum of Paris: a systems approach to accelerating climate finance. Climate Policy Institute: London, UK 
Park J, Conca K, Finger M (eds) (2008) The crisis of global environmental governance: towards a new political economy of sustainability. Routledge, New York, NY

Paterson M (2018) Business in Sprinz D, ed, Global climate policy: actors, concepts, and enduring challenges. MIT Press: Cambridge, MA

Pearce F (1992) Earth at the mercy of national interests. New Scientist, 20 June, 4

Roberts JT, Parks BC (2007) A climate of injustice: global inequality, north-south politics, and climate policy. MIT Press, Cambridge, MA

Rodale Institute (2014) Global climate policy: actors, concepts, and enduring challenges. Kutztown, PA: Rodale Institute

Rubin A (2018) A miserably hot summer is fast becoming the norm. New York Times. August 5, 6.

Selin H (2016) Climate finance and developing countries: the need for regime development. Global Economic Governance Initiative Working Paper 009. Boston, MA: Boston University

Sengupta S (2018) Fastest drying in 2,000 years imperils millions. New York Times. March 12.

Shine T (2017) Supporting access to finance for climate action. Stockholm: Sida

Soares M, et al (2017) Delivering real change: getting international climate finance to the local level. IIED: London, UK

Steffen W et al (2015) The trajectory of the Anthropocene: The Great Acceleration. Anthropocene Rev 2(1):81-98

Stockholm Resiliency Centre (2018) Six transformations needed to achieve the UN Sustainable Development Goals. July 10. http:// www.stockholmresilience.org/research/research-news/2018-0710-six-transformations-needed-to-achieve-the-un-sustainabledevelopment-goals.html
Stubbs W, Cocklin C (2008) Conceptualizing a sustainability business model. Organ Environ 21(2):103-127

United Nations (2014) Report of the Intergovernmental Committee of Experts on Sustainable Development Financing. New York City: United Nations.

Tollefson J, Gilbert N (2012) Earth Summit: Rio Report Card. Nature. 486, June, 20-23.

UN Environment (2016) Adaptation Gap Report. Nairobi, Kenya: UN Environment.

UNFCCC(a) (2018). e-Handbook: Adaptation. Bonn, Germany: UNFCCC. https://bigpicture.unfccc.int/content/adaptation.html\#conte nt-adaptation

UNFCCC(b) (2018). e-Handbook: Mitigation. Bonn, Germany: UNFCCC. https://bigpicture.unfccc.int/content/adaptation.html\#conte nt-mitigation

Watson C, Bird N, Schalatek L (2018) 10 things to know about climate finance in 2017. Overseas Development Institute: London, UK

World Resources Institute (WRI) (2018) Adaptation Finance Washington D.C.: World Resources Institute. https://www.wri.org/ourwork/project/adaptation-finance

Zhang W, Pan X (2016) Study on the demand of climate finance for developing countries based on submitted INDC. Adv Clim Chang Res 7(1-2):99-104

Publisher's Note Springer Nature remains neutral with regard to jurisdictional claims in published maps and institutional affiliations. 